\title{
Analysis of the Maternity Benefits Amendment Act, 2017 and its Implications on the Modern Industrial Discourse
}

\author{
Manvendra Singh Jadon* and Ankit Bhandari ${ }^{\dagger}$
}

\section{Abstract}

As a recognition of the crucial role played by women, it is vital that governments move away from and rocentric laws and work towards achieving social justice, both in the organized and unorganized sectors. The concept of social justice has manifested itself in the Maternity Benefits Act, 1961 and its subsequent amendments. Complementary to this law, the judiciary has played a vital role in rendering judgments that involve liberal interpretations of the provisions of the law so as to be beneficial to the labor community. This is evidenced in the case of B. Shah v. Labor Court, Coimbatore. However, lacunas and complications continue to exist. The Legislature and the Judiciary must identify the factors that are obstructing the achievement of social and economic equality of women. This paper seeks to analyze judicial interpretations and the legislative intent of the 2017 amendment to the Maternity Benefits Act, 1961.

Keywords: Beneficial Construction, Computation of Leave, Labor Force, Maternity Protection, Social Justice

\section{Introduction}

As Quoted by Gabriel Ivbijaro, 'Social Justice is an integral part of Justice in the generic sense. Justice is the genus of which social

\footnotetext{
*National Law University, Assam, India; msjadon@nluassam.ac.in

${ }^{\dagger}$ National Law University, Assam, India; ankitbha58@gmail.com
} 
justice is one of its species'.1This is highly significant in the analysis of current labor legislations. A law that constantly transforms and evolves into new paradigm by expanding itself to cater to the needs of the society at a point in time is said to be socially just. The principles of social justice underlie the complex social reformation of relieving the downtrodden and the underprivileged from the existing handicaps in the modern social structure. The goal, herein, is to give the distressed individuals, an access to incorporeal resources of justice, which has the capacity to fend off the evil of penury, in the greater interest of the social existence and development. The essence of social justice is to attain a substantial degree of social, economic and political equality which is quite a legitimate expectation under the constitutional as well as moral terms. In India, a country that is divided by varied castes and communities, it has taken a herculean effort to accomplish the objective of eliminating inequalities and rendering uniform opportunities for all citizens of the country, within the realm of social, economic and political affairs.

The judiciary has always been at the helm of social resurrection in democratic societies. It is the only forum that upholds the rule of law in the truest sense of the word aiding in social readjustment -an essential pre-requisite in establishing a coherent socio-economic order. ${ }^{\text {In }}$ the case of Life Insurance Corporation of India $v$. Consumer Education and Research Center, ${ }^{4}$ while addressing the rights of unorganized laborers, the Supreme Court noted that Articles 41and 47of the Constitution of India seek to preserve the social fabric of the nation by imposing duty on the State to formulate policies that raise the standards of the living and improve public health. In the case of Delhi Gymkhana Club Ltd v. Employees State Insurance

1 Gabriel ivbijaro, Mental Health: The Aspiration to Reality Gap, Mental Health in Family Medicine $(8.2,2011)$.

2 Dr. Panday Mayuri, Social Justice; a Dream or Reality, AIR May 2009 Journal 79.

${ }^{3}$ Dr. Dipti Rekha Mohapatra, Role of Judiciary for the Social Security and

Protection of Women Labour in India 17 IJTRA, 25,31 (2015).

4 Life Insurance Corporation of India v. Consumer Education and

Research Center AIR 1995 SC 1811. 
Corporation, ${ }^{5}$ the court adopted a liberal interpretation in pursuance of the objects of the Employees State Insurance Act,1948, as it is a beneficial piece of legislation aimed at securing the well-being of the employees, by providing benefits in cases of sickness, maternity and employment injury, etc. A strict interpretation of social welfare legislations will invariably have the effect of defeating the objects of the Act.

This paper explores the changing landscape of women's role in today's society by highlighting the elements of social justice that is infused into legislations and judicial pronouncements. With the increased degree of participation of women in the spheres of public life, it is essential to protect them from the archaic and illogical prejudices that are harbored against them in the society. The Indian government has taken several significant steps in ensuring equal rights and opportunities to women against the backdrop of multifarious cultural practices, traditions and norms that relentlessly hinders achievement of equality. The Maternity Benefits Act, 1961was enacted to provide women an equitable environment and a level playing ground in work places. The recent amendment to the Act in 2017 is the consequence of revolutionary steps that were taken by women's rights groups and labour justice unions to include women laborers. This paper seeks to analyze the effect of the aforementioned amendment on modern industrial discourse. As the scope of the paper is limited to the analysis of the factors of development related to employment of women under the Maternity Benefits Act, 1961, it is restricted to addressing the relevant provisions of the social security legislations and highlights the need for organization in the sector.

\section{A Statistical Analysis of Women's Labor Force in Industries}

To become a mother is the most natural phenomenon in the life of a woman. Whatever is needed to facilitate the birth of child to a woman who is in service, the employer has to be considerate and

5 Delhi Gymkhana Club Ltd v. Employees State Insurance Corporation (2014) SCC 853. 
sympathetic towards her and must realize the physical difficulties which a working woman would face in performing her duties at the workplace, during both pre and post-natal phases. ${ }^{6}$

It is an established fact that women are in a disadvantageous position when compared to labour work force, comprising of men. ${ }^{7}$ On an International front, the women workforce on an average, are paid less in comparison to men due to several factors; with the majority of these gender gaps existing in Southern Asia, Middle East and Africa. ${ }^{8}$ As per the data released by the World Bank, women labour force in our country constitutes only a mere $24.3 \%$ of the total workforce, which is on a downward spiral, in comparison to the figures in the year $1990 .{ }^{9}$ As per the International Labor Organization (ILO), most of the countries provide for Maternity Benefits, but these nations grossly fail at the implementation level. ${ }^{10}$ On a domestic level, it has been forecasted that India will add 110 million working personnels to its total labour force. After the inclusion of women, the estimate increases by 68 million by the year 2025; allowing the growth of the Gross Domestic Product (GDP) of the country by 16\%.11 In a report

${ }^{6}$ Municipal Corporation of Delhi v. Female Workers (Muster Roll) and Anr. (2000) 3 SCC 224.

7 Varsha Kumari, Problems and Challenges Faced by Urban Working Women in India, (May, 2014) available at:http://ethesis.nitrkl.ac.in/6094/1/E208.pdf

8 Facts and Figure, Economic Empowerment, U.N WOMEN, (July, 2018) available at:http://www.unwomen.org/en/what-we-do/economicempowerment/facts-and-figures\#notes

9 Labor force participation rate, female (\% of female population ages 15+) (modelled ILO estimate), INTERNATIONAL LABOUR ORGANIZATION, ILOSTAT DATABASE, (September, 2018) available at: http://data.worldbank.org/ indicator/ SL.TLF.CACT.FE.ZS?year_ high_desc $=$ false

10 ILO, Women at Work Trends 2016, INTERNATIONAL LABOUR OFFICE, INTERNATIONAL LABOR ORGANIZATION, GENEVA, (2016) available at:http://www.ilo.org/wcmsp5/groups/public/dgreports/--dcomm/---publ/ documents/ publication/ wcms_457317.pdf

11 Women in Workforce in India, India, Equity in Business Leadership, CATALYST, (July. 11 ${ }^{\text {th }}, 2018$ ) available at: http:// www.catalyst.org/ knowledge/women-workforce-india\#footnote37_aooj3w2 
published by National Sample Survey Office (NSSO), it has been highlighted that only a mere 24.8 women out of 100 women worked in rural areas. In contrast, the men were at a strong 54.3.12The participation of women was even more abysmal in the urban economies. For every 54.6 men who were employed, there were a disheartening14.7 working women. The Indian government has been making sustainable efforts to ensure gender parity and social security for female labor force in India with the effectuation of schemes like Mahatma Gandhi National Rural Employment Guarantee Act (MNREGA), Rajiv Gandhi National Creche Scheme for the Children of Working Mothers, Indira Gandhi Matritva Sahyog Yojana (IGMSY). The IGMSY is a conditional maternity benefit scheme that has aided in bringing about a considerable change. However, it has been unable to significantly inculcate it into the social security policy framework in India. The National Policy for Women ${ }^{13}$ goes a long way in addressing the social security mechanism for women at all levels but contrastingly, it is still in a nascent stage and is predicted to take a long time before it is implemented. Empowerment of women lie in their growth at all levels, including education, health, employment and power positions. ${ }^{14}$ Such empowerment measures ${ }^{15}$ must be taken into

12 Pravin SRivastava et aL., Women and Men in India, Ministry of StATISTICS AND PROGRAMME IMPLEMENTATION 2017 67-68 (19th ed. 2017).

${ }^{13}$ National Policy for Women 2016, GOVERNMENT OF INDIA, MINISTRY OF WOMEN AND CHILD DEVELOPMENT, (2016) available at: http://wcd.nic.in/sites/default/files/draft $\% 20$ national $\% 20$ policy $\% 20$ for\%20women\%202016_0.pdf

${ }^{14}$ Ministry of Women and Child Development Government of India, XII Five Year Plan Report of the Working Group on Women's Agency and Empowerment, PLANNING COMMISSION (2016) available at:http://planningcommission.nic.in/aboutus/committee/wrkgrp12/ wcd/wgrep_women.pdf

${ }^{15}$ Deloitte, Report on Enablers for Women Empowerment at Workplace in India, BCIC (May, 2017) available at:https://bcic.in/ upload_images/ articals/Report\%20on\%20Enablers\%20for\%20Women\%20Empowerme nt $\% 20$ at $\% 20$ Workplace\%20in\%20India.pdf 
consideration in both, the organized and unorganized sectors where women are still facing issues with regard to social benefits ${ }^{16}$.

\section{Analysis of the Maternity Benefits Framework}

Several major amendments were made to the Maternity Benefits Act, 1961 by virtue of 2017 Amendment Act. Some of the major amendments that were brought in were the provisions of the Sixth Central Pay Commission (For Maternity and Child Care Leave)and the Central Civil Services (Leave) Rules, 1972 (CCSL Rules) ; which for the first time implemented a 'Six Months Paid Leave Policy' for the Central Government Employees. Globally, the ILO formulated the Maternity Protection Convention 17 in 2000, which mandated that no less than 14 weeks is to be granted to women as maternity leave. Additionally, the United Nations has recognized Maternal Health as one of the Sustainable Goals ${ }^{18}$. Article 25 of the Universal Declaration of Human Rights states that Motherhood and childhood are entitled to special care and assistance and building on this premise ${ }^{19}$, The Convention on the Rights of Child specifically states that "to ensure to the maximum extent possible child survival and development, render appropriate assistance to parents and legal guardians in the performance of their child rearing responsibilities and ensure the development of institutions, facilities and services for the care of children". ${ }^{20}$ The provisions of

16 Azadeh Barati et., Challenges and Problems Faced by Women Workers in India, CNWIMS \& R, 77 (2015); See ILO Report, INTERNATIONAL LABOUR ORGANIZATION, (2007), available at: http:// www.ilo.org/ Wcmsp5/groups/public/---dgreports/---gender/ documents/publication/wcms_087314.pdf

17 Convention concerning the revision of the Maternity Protection Convention (Revised), 1952 (Entry into force: 07 Feb 2002); Adoption: Geneva, 88th ILC session (15 Jun 2000).

18 United Nations, Sustainable Goals, Goal 3: Ensure healthy lives and promote well-being for all at all ages; UNITED NATIONS, (Jan. 1'st, 2016) available at:http://www.un.org/sustainabledevelopment/health/

19 Gordon Brown, The Universal DeClaration OF Human Rights IN THE 21st CENTURy THE Universal DeClaration OF Human Rights IN THE 21ST CENTURY 41-42.

${ }^{20}$ Id. Art. 6 and art. 8 
the aforementioned international instruments were synthesized in the formulation of the Maternity Benefits Act, 2017 during the $44^{\text {th }}$, $45^{\text {th }}$ and the $46^{\text {th }}$ session of the Indian Labor Conference. ${ }^{21}$ The Act came into effect on 1stApril, applies to all women workers who are employed in both the organized and unorganized sectors, if the establishments are covered under§ 2 of the Act. ${ }^{22}$ There are several legislations in the labor and the industrial policy that discusses and provides for maternity benefits for women viz. The Factories Act, 1948, The Building and Other Construction Workers (Regulation of Employment and Conditions of Service) Act, 1966, and the unorganized Workers' Social Security Act, 2008. The Employees' State Insurance Act, 1948 deals with maternity benefits as one of its prime objects of enactment and lays down a leave structure of 12 weeks for the mother, in addition to providing a regulatory framework ${ }^{23}$ for its effective implementation. However, the scope of the application of the Act is limited to government establishments which is in direct contradiction to the Supreme Court's direction that the benefits under the Act would squarely apply to every woman irrespective of the fact that in what manner she is employed, ranging from situations involving employment as daily wagers, casual employees and contractual employees. ${ }^{24}$ The Amendment Act has been pivotal in shaping a policy for providing crèche facilities to the children of working women. The Act also extends an exclusive opportunity to the working women to work

21 Ministry of Labour and Employment, Clarifications, LABOUR MINISTRY, (April. 12 $2^{\text {th }}, 2017$ ), available at: http://labour.gov.in/ sites/ default/files/ The\%20Maternity \%20Benefit \% 20\%28 Amendment\%29\%20Act\%2C2017\%20-Clarifications.pdf

22 Ministry of Labour\& Employment, Clarifications Issued By the Ministry of Labour\& Employment In Relation To Maternity Benefit (Amendment) Act, 2017, KHAITAN \& CO., (April. 13 ${ }^{\text {th }}, 2017$ ), available at: https:// www.khaitanco.com/PublicationsDocs/Khaitan\%20\&\%20Co\%20Ergo -Newsflash-13April2017.pdf

23 The Employees' State Insurance (General) Regulations, 1950, No. RS/5/48.

24 Dr. Parul Mishra v. State of U.P., Service Bench No. 67 of 2010; Mrs. Priyanka Gujarkar v. Registrar General, W.P. No.17004/2015. 
from home. ${ }^{25}$ However, this can be disputed on a contractual basis with respect to the terms that have been settled between the working women and the employer.

With the number of paid leave having increased to 26 weeks, India now stands among the top sixteen nations providing the longest maternity leave and the third single largest after Norway and Canada. ${ }^{26}$ However, India is also among those few nations that does not provide for public disbursement of benefit under such social benefits Acts. Hence, the employer has to bear the cost of providing benefits which has the potential to significantly hamper the future employment opportunities for working women. ${ }^{27}$ There is a plethora of beneficial legislations that exist for the development and progress of women ranging from Convention for the Elimination of Discrimination Against Woman (CEDAW) to Constitution of India, 1949. However, there exists a failure in having a ground level impact which is starkly evident from the depreciating rates of women in the labor market. With India being a developing nation and a budding superpower, ${ }^{28 i t}$ cannot be overlooked that a country's economic, social and political

${ }^{25}$ Khaitan \& Co., Maternity Benefit (Amendment) Act, 2017 Is Effective from 1 April 2017, ERGO, Newsflash, (April. 3 ${ }^{\text {rd }}$ 2017), available at:https:/ / www.khaitanco.com/PublicationsDocs/Khaitan\%20\&\%20C o\% 20Ergo-Newsflash-3April2017.pdf

26 Jean D'Chuna, India's Bold Maternity Benefit Act Can Become a Game Changer if it Addresses Current Limitations, E. \& P. WEEKLY, 04 Aug, 2018, Vol. 53, Issue No. 31.

27 Ajay Raghavan, Maternity Benefit Amendments: Closer to Reality, TRILEGAL, (Sep. $\quad 4^{\text {th }}, \quad 2017$ ) available at:http:// www.employmentlawalliance.com/firms/trilegal/articles/maternitybenefit-amendments-closer-to-realityMedhavi Arora, India's generous maternity leave may be bad for women, CNN MONEY, (March. 30th, 2017) available at:http:/ / money.cnn.com/2017/03/30/news/economy/indiamaternity-leave-law-employment-hiring/index.html

${ }^{28}$ Goldman Sachs, Think India- The rise of the world's next superpower $\mathcal{E}$ what it means to every American, HARVARD UNIVERSITY, (August. 16, 2007) available at: https://www.innovations.harvard.edu/ sites/ default/ files/53231.pdf 
development lies in the growth of it women. ${ }^{29}$ In order to have the desired effect, strong legislations like the Maternity Benefits Act must be followed by a strategic application of laws in its implementation by independent authorities.

\section{Social Justice and Maternity Benefits}

Given the social fabric and disparities of the country, the Courts have fundamentally been flexible in their approach towards interpretation of socially sensitive concerns, specifically when the question before the court entails issue of inequality. ${ }^{30 I t}$ must be noted that the Constitution of India establishes equality of the sexes under Article 14 and creates a special provision for women under Article 15(3). ${ }^{31}$ The object that was sought to be achieved was brought out by the Supreme Court in the case of Government of Andhra Pradesh v. P.B. Vijayakumar EAnr. ${ }^{2} \mathrm{On}$ account of women being socially and economically handicapped for centuries and in order to eliminate their socio-economic backwardness, the State, under Art 15(3) was to improve the women's participation in all activities under the supervision and control of the State and it can be in the form of either affirmative action or reservation.

Furthermore, the Directive Principles of State Policy (DPSP) create an obligation on the State under Articles 38, 39 and 42to reduce the inequalities and provide social justice to women; a stance which was taken by the Court in the case of Bandhua Mukti Morcha $v$. Union of India ${ }^{33}$.To affirm the fact that the DPSPs are agents of social upliftment of women, the Court in the case of John Vallamattom $v$.

29 Kalpana Kochhar \&Sonali Jain-Chandra \& Monique Newiak, Women, Work and Economic Growth: Levelling the Playing Field, INTERNATIONAL MONETARY FUND, (2016) available at:https:/ / www.elibrary.imf.org/fileasset/misc/excerpts/womenwork-excerpt.pdf

30 Air India Statutory Corporation v. United Labour Union, AIR 1997 SC 645; See Also Steel Authority of India v. National Union Waterfront Workers, (2001) 7 SCC 1.

31 Shamsher Singh v. State of Punjab, AIR 1970 P\&H 372.

3219954 SCC 520.

331984 AIR 802. 
Union of India ${ }^{34}$ categorically stated that the DPSPs contained in Articles 39(a), 39(d) and 39(e), are interpreted by the Supreme Court in a manner that would align with the conferring of economic improvement on women.

Even though the provisions of the laws have been constructively interpreted to be inclusive of the principles of social justice, i.e. to provide an equal platform to all sections of the society, there have been a few situations when the courts have opted to narrowly interpret the provisions of law in the light of the prejudicial social customs, personal laws and the literal language of the text. ${ }^{35}$ Such an approach is not only narrow but oppressive as well, especially when read in conjunction with the principles of social justice. In the modern context, a majority of the social evils have been vanquished with the help of judgments like Shayara Bano v. Union of India and Ors ${ }^{36}$ and Indian Young Lawyers Association v. State of Kerala (Sabarimala) ${ }^{37}$. However, a few instances of strict interpretation of social welfare legislations are also a possibility, as evident from the case of Whirlpool of India Ltd. v. Employees' State Insurance Corporation 38 , wherein the Court noted that, any provision wherein two interpretations may be possible, would deserve such a construction as would be beneficial to the working class but, at the same time, we cannot pass off the plain language of a provision.

In the pursuance of social justice, as evident from the legislative and judicial history, women have been given a separate status. This is not a case of dilution of Article 14 and the concept of equality stated therein, but rather, justice through equality for the unequals. ${ }^{39}$ The Maternity Benefits Act, along with the principles of social justice and the DPSPs, are agents of the social amelioration of women. The cost of conferring benefits on the female employees is

\footnotetext{
34 AIR 2003 SC 2902.

35 P.E. Matthew v. Union of India, AIR 1999 Ker 345.

362017 SCC Online SC 963.

37 Writ Petition (Civil) No. 373 of 2006.

38 (2000) 3 SCC 185.

39 Indra Sawhney v. Union of India and Ors, AIR 1993 SC 477.
} 
overwhelmed and outweighed by the benefits arising from it.40This was reiterated by the Delhi High Court in Dr. Ankita Baidya v. Union of India $\mathcal{E} O r s^{41}$. The Court noted that that the Maternity Benefit Act, being in the nature of a piece of social welfare legislation, it's reach and sweep has to be as expansive as possible, rather than limited by any pedantic considerations of word or phrase.

In contrast to the objects of the Act, there have been several instances that has demonstrated that women still lack a voice, suffer abuse during employment, experience exclusion, face inequality and have poor knowledge of their rights. ${ }^{42}$ This has led to a slew of problems for working women, in the context of them being disabled from availing the benefits that are guaranteed to them under the modal system of law. A majority of these problems are faced by women who are working in the unorganized sector unlike the women in the organized sector; who are aware of their rights under active employment. ${ }^{43}$ The law relating to beneficial legislations, specifically the Maternity Benefits Act has been overtly discussed by the judiciary in the recent decades; the prime example among them being the B. Shah $v$. Presiding Officer, Labor Court, Coimbatore 44 . The doctrine of 'beneficial rule of construction' ${ }^{45} \mathrm{was}$ conclusively and comprehensively discussed in relation to social legislations like the Maternity Benefits Act. Even though the objective behind social legislations is to advance the welfare of the masses, provide improved access to justice and give impetus to reasonability, such primary constituents of the great legislative

40 Radhakishan Ramnath v. State of Bombay, (1959) IILLJ 177 Bom; LancoAnpara Power Ltd v. State Of Uttar Pradesh And Ors, 2017 (I) I.L.R - CUT- 187 (S.C.)

41 W.P. (C) 8748/2018 \& CM APPL.45209/2018.

42 T.N Dhar, Women's Empowerment and Social justice In India (With Special Reference to U.P.), 10 INDIAN JOURNAL OF PUBLIC ADMINISTRATION, 638 (2014).

${ }^{43}$ Municipal Corporation of Delhi v. Female Workers (Muster Roll) \&Anr. AIR 2000 SC 1274.

441978 A.I.R 12.

45 GRANVILLE SHARP, MAXWELL ON INTERPRETATION OF

STATUTES, 68 (Sweet \& Maxwell Limited, London, 10th ed. 1953). 
intent in majority of these promulgations 46 have failed to materialize in reality. The lack of access to these legislations to the vulnerable and marginalized group of women still remains a hurdle.

As the B. Shah ${ }^{47}$ case was not only a minor consideration about computation of holidays but rather the whole gamut of social welfare for working women and its sanctity was hanging by the sword. Two of the major contentions before the court were that the Legislative Intent behind the enactment of the statute and subsequent Interpretation of the statute ${ }^{48}$ and Computation of leave for the grant of Maternity Benefits. ${ }^{49}$ On the first issue, it was held that 'While interpreting beneficial pieces of legislations such as Maternity Benefits Act, emphasis must be granted to its objectives which in this case happens to provide much needed social justice to women workers employed in certain work establishments. The Court further added that a beneficial legislation effectively exists within the purview of Article 42 of the Constitution and a Beneficent Rule of Construction doctrine must be applied to such Acts'50. This rule of construction would enable the woman worker not only to subsist but also to make up her dissipated energy, nurse her child, preserve her efficiency as a worker and maintain the level of her previous efficiency and output.

The goal of providing such benefits is to preserve the efficiency of the working women which is beneficial to the long term interest of

46 Budhan v. Nabi Bux AIR 1970 S.C. 1980.

47 B. Shah v. Presiding Officer, Labor Court, Coimbatore, 1978 A.I.R 12.

48 Statement of Object and Reasons, Maternity Benefits Act, 1961, INTERNATIONAL LABOUR ORGANIZATION,(May 23rd, 2017) available at: http://www.ilo.org/ dyn/travail/docs/678/ maternitybenefitsact1961.pdf; See Modern Movies v SB Tiwari, (1966) 1 Lab LJ 763.

$49 \S 5$, Maternity Benefits Act, 1961, Act No. 53 of 1961, Acts of Parliament, 1961 (India).

50 LalappaLingappa\&Ors. v. Laxmi Vishnu Textile Mills Ltd., 1981 AIR 852; See S. Appukutan v. Thundiyil Janaki Amma \&Anr., 1988 AIR 587; See Also Transport Corpn. of India v. ESI Corpn. (2000) 1 SCC 332; Buckingham and Carnatic Co. Ltd. v. Venkatiah, AIR 1964 S.C. 1272. 
both the employers and employees. ${ }^{51}$ One pertinent point dealt with indirectly by the Court was the overall health effects of pregnancy on women and how improper care can lead to deficiencies and diseases in the Child. ${ }^{52}$ Such an analogy can be drawn from the fact that if benefits are not given to make up for the dissipated energy then the women could not give sufficient time to nurse their child leading to health issues in the child. In Municipal Corporation of Delhi v. Female Workers (Muster Roll) and Anr53, it was noted that to become a mother is the most natural phenomena in the life of a woman and whatever is needed to facilitate the birth of child to a woman who is in service, the employer has to be considerate and sympathetic to give and must realize the physical difficulties which a working woman would face in performing her duties at the work place while carrying a baby in the womb or while rearing up the child after birth.'

This judgment along with the decisions in Dr. (Smt.) Hemlata Saraswat v. State of Rajasthan ${ }^{54}$ and Ors and Dr. Swati vs Govt. of NCT of Delhis5are monumental in the manner that it sets a benchmark for the interpretation of social legislations alongside providing a certain leverage to the objective of achieving sustainable growth of women and children sought by a multitude of Welfare Legislations and International Conventions. ${ }^{56}$

The second issue dealt with by the Court was whether the 'Computation of Days' for granting the Maternity benefits by the appellant establishment in the case was detrimental to the welfare of the women and wrongful conduct on part of the establishment,

\footnotetext{
${ }^{51}$ E.S.I.C. v. Sri Krishna Bottlers (P) Ltd., (1977) IILLJ 227 A.P, pp.65.

52 ANITA AbraHAM ET AL., CRITICAL ASSESSMENT OF LABOUR LAWS, POLICIES AND PRACTICES THROUGH A GENDER LENS (National Resource Centre for Women) (2014).

53 (2000) 3 SCC 224.

54 OA No.1761/2015.

55 RLW 2008 (2) Raj 1397.

${ }_{56}$ Maternity Protection Resource Package, International rights and guidance on Maternity Protection at work (Module 5), INTERNATIONAL LABOUR ORGANISATION, 2012, pp.1-9.
} 
to exclude Sundays as non-payable leave. ${ }^{57}$ The court answered the question in the affirmative and held that indeed the connotation of the term week inserted in the Act include Sunday for which the benefit amount must be paid irrespective of the fact that it is generally a wage less day. ${ }^{58}$ It was further stated that it was the primary intention of the legislature that any future computation of benefits under this Act must be made for the entire period of the absence of the women worker i.e. for all the days including Sundays which are unpaid leave day. ${ }^{59}$ This computation was not only a fact based question, but it was indeed a thread to bind figurative value with that of materialistic significance. Thus, the words 'week' and 'period' 60 are of strong significance. If the legislature intended to ward off wage less days from Computation, then they language used in construing the provisions would be different This Act is promulgated to benefit the working women and not the employers ${ }^{61}$, the aims of whom are to increase their own profits and resources. Hence if the benefits do not reach the targeted community, the purpose of the Act remains unsatisfied.

On a counter egalitarian viewpoint, it can be said that a week for rest of the employees includes Sunday as only a wageless holiday,

57 Ram Bahadur Thakur (P) Ltd. vs. Chief Inspector of Plantations, (1989) IILLJ 20 Ker.

58 Parthasarathy M. v. Deputy Commissioner of Labour (Appeals) and Ors. A.I.R 1986 SC 458.

59 Mamundiraj N. and Ors. v. Bharat Heavy Electricals Ltd., Trichy and Anr; See Tata Tea Limited, Velonie Estate v. The State of Tamil Nadu represented by its Secretary to Government, Labour and Employment Department andOrs.

60 Management of Sri Akilandeswari Mills Ltd., Salem v. Assistant Commissioner of Labour (Controlling Authority under Payment of Gratuity Act), Salem and Ors, 2000 (1) L.L.J 1411.

61 Harjinder Singh v. Punjab State Warehousing Corporation, 2010 (1) S.C.T 725; See Management of Sri Akilandeswari Mills Ltd., Salem v. Assistant Commissioner of Labour (Controlling Authority under Payment of Gratuity Act), Salem and Ors., 2000 (1) L.L.J 1411; See Also American Express International Banking Corporation v. The Management of American Express International Banking Corpn. (1985) 4 S.C.C 71. 
but women in labor cannot be taken on the same pedestal as other employees. They are a vulnerable group who are in need of care, rest and nutrition.62 It cannot be ignored that payment for the wageless day cause an economic hardship for the employers and might create a situation of a financial burden on them but then the pregnant working women are the responsibility of not only the state, society but employers as well. ${ }^{63}$ Furthermore, such a computation would be conducive to the interest of both the employer and employee as the women could invest the said amount in giving herself and her child the best care which in turn would help her maintain desirability of work and efficiency after she re-joins the establishment. ${ }^{64}$

\section{Commercial Implications of the Gender Neutral Aspects of the Maternity Benefits Act}

The Maternity Benefits Act is a step forward in increasing gender inclusivity but stereotypes may be observed in the Act. For instance, unlike progressive countries such as Norway, Sweden, Ireland and several others65, India does not have a mandatory provision for paid paternity leave ${ }^{66}$, despite several national and international industrial establishments and corporations having

62 Debi S. Saini, Social Security Law in India Maternity Benefits, WOLTERS KLUWER-LAW AND BUSINESS ONLINE, 2011 132-134.

63 See Preetha Nishanth Ravindran \& Ajay Solanki \& Vikram Shroff, Maternity Leave In India Increased To Six Months, NISHITH DESAI, (March. 29th, 2017) available at: http://www.nishithdesai.com/ information/news-storage/news-details/article/maternity-leave-inindia-increased-to-six-months.html

64 The Kerala State Electricity v. Siniya Mol, WA No. 2220 of 2007.

65 General Infographic, Global Paternity Leave Trends, MERCER, (2016) available

https://www.mercer.com/content/dam/mercer/attachments/global /Talent/parental-leave/gl-2016-global-parental-leave-paternity-leavetrends-infograhic-mercer.pdf

66 Paternity leave provided by some firms in India: Private sphere recognizes changing times, MEDIA INDIA (July. 17th, 2017) available at: https://mediaindia.eu/social-vibes/paternity-leave-provided-bysome-firms-in-india/ 
enacted parental leave provisions in their own rules and regulations ${ }^{67}$. Such abandonment leaves fathers in distressed when it comes to care and nourishment of their new born children. There has been initiation in the Parliament to pass the Paternity Benefits Bill, 201768 but nothing has substantiated till now. The ILO Report also highlights the need and importance of parental leave similar to that of maternal leave and several other employment benefits that must be equally shared. ${ }^{69} \mathrm{As}$ of now, there is nothing in the Maternity Benefits Act which talks about paternity leave, given the 'Statement of Objects and Reasons' of the Maternity Benefits Act. Although various other Central Acts and Rules ${ }^{70}$ provide for paternal leave, there still remains a huge deficit in the benefits offered to women and men in the same working sector. Paternity Benefits Bill details out provisions which can profoundly affect gender discrimination positively. ${ }^{71} \mathrm{To}$ achieve gender equality in the context of an increasing women workforce, a descriptive and sound framework is needed.

As envisaged by the legislators, the preponderance of the benefits enclosed under the Act falls in the favor of the woman

67 Newsflash, 3 Months Leave and More: What the New Paternity Benefit Bill Can Mean for Dads, THE BETTER INDIA (Sep. 19th, 2017) available at: https:/ / www.thebetterindia.com/115826/paternity-benefit-billpushes-for-three-month-leave-for-new-fathers/

68 New Bill Proposes Paternity Leave across All Sectors, NDTV, (Sep. 17th, 2017) available at: https://www.ndtv.com/india-news/paternityleaveacross-all-sectors-proposes-private-members-bill-1751408

69 Addati \& Laura \& Cassirer \&Naomi \& Gilchrist \& Katherine, Maternity and Paternity at work: Law and Practice across the World, INTERNATIONAL LABOUR OFFICE. - GENEVA: ILO, 2014.

70 Office Memorandum, Ministry of Personnel, Public Grievances and Pensions, (July. 22nd, 2009) available at: http:// cara.nic.in/ pdf/ circular/Adoption\%20leave.pdf;See Rule 43-A and 43-C of the Central Civil Services (Leave) Rules, 1972; See Also Kakali Ghosh v. Chief Secretary, Andaman \& Nicobar Administration and Ors., (2014) 15 SCC 300.

71 BIBLE HR, (2017)available at: https:/ / biblehr.com/wp-content/ uploads/2017/09/Paternity-Benefits-Bill-2017.pdf 
employee. ${ }^{72}$ However, the Act overlooks the stark reality of the rising commercial interests of the employers (Neither the $\S 10,12$ and 17 of the Act or Rule 4, 5,6,7,8,9,10 and 11 of the Maternity Benefit (Mines and Circus) Rules, 1963 talks about balance of interest of employees and employers), and this inadvertently leads to a mismatched balance of interests. Although the Act stipulates that an Employer can neither dismiss a woman on account of leave as per the directions of the Act, ${ }^{73}$ nor deny her the benefits under the Act because of procedural irregularities ${ }^{74}$, it does not discuss the issues arising during the pre-employment period and postpregnancy period ${ }^{75}$. Such a discussion becomes inherently necessary because the employers are not barred from appointing women as employees, if they are pregnant ${ }^{76}$. In addition to this, the employers may also terminate the services of those pregnant women who get adequate maternity benefits. ${ }^{77}$

These issues have been somewhat clarified by the apex court in Neera Mathur vs Life Insurance Corporation of India, ${ }^{78}$ wherein the court safeguarded the interest of a woman who was wrongfully terminated on the ground of non-disclosure of pregnancy at the time of the appointment. Although the court clearly stated in precise terms that asking for such disclosures is humiliating and

72 Statement of Objects and Reasons, Maternity Benefits Amendment Act, 2017, Act No. 6 of 2017, Acts of Parliament (India).

$73 \S 12$, Maternity Benefits Act, 1961, Act No. 53 of 1961, Acts of Parliament, 1961 (India).

$74 \S 6$ (6) Maternity Benefits Act, 1961, Act No. 53 of 1961, Acts of Parliament, 1961 (India).

75 Labour Law Offices, Legal Rights of Pregnant Women at Work, LABOUR LAW OFFICES, (June. 15 $5^{\text {th }}$ 2009), <https:// labourlawoffices. wordpress.com/2009/06/15/legal-rights-of-pregnant-women-atwork/>.

76 Parag Bhide, Legal HR: Can you fire a pregnant woman employee, KHAITAN \& CO.(Dec. 5th, 2017) available at: https:// www.khaitanco.com/PublicationsDocs/PeopleMattersKCOCoverage5Dec17ANP-Parag.pdf

$77 \S 12$ (2) (2), Maternity Benefits Act, 1961, Act No. 53 of 1961, Acts of Parliament, 1961 (India).

781992 A.I.R 392. 
dilutes the right to maintain secrecy, it did not earmark a definite principal in this regard. Moreover, judgments along the line discuss the termination of women after appointment, but none enumerate the issues of significance during the appointment of a pregnant woman. 79

\section{Employers' Interests and Restrictions}

The lacunas in the law raise the debate between the commercial goals of the modern world versus beneficial construction of social welfare legislations. It must be taken into account that in general economic sense, every employer seeks maximization of profits through an increase in production and the basic tenants of this production function are 'labor utilization'80 and 'production deficit' 81 . Due to such premeditated goals, it becomes imperative that employers are, at large, not concerned with the benefits disbursement of women employees. With such points of consideration, public disbursement of maternity benefits becomes imminent so the employers are not overburdened with the social securities guaranteed under the Act. Such public disbursement schemes could be incorporated in the State Amendments, so that the Centre is not segregated in terms of economic burdens. In addition to this, disbursement of medical bonus also needs to be made if no pre-natal confinement and postnatal care were provided by the employer. ${ }^{82}$

On the other hand, in-benefits and post-benefits period are also very tumultuous for pregnant women employees. During the in-

${ }^{79}$ Charu Khurana v. Union of India, (2015) 1 S.C.C 192.

80 Trond Petersen \&Vermund Snartland, \& Eva M. Meyersson Milgrom, (2006),Are Female Workers Less Productive Than Male Workers?, IRLE Working Paper No. 139-06.

81 Walby\& Sylvia \& Olsen \& Wendy (2002), The Impact of Women's Position in the Labour Market on Pay and Implications for Productivity, Women and Equality Unit (DTI).

82 Legislative Brief, The Maternity Benefits (Amendment) Bill, 2016, PRS Legislative Research, (Oct. 27th, 2016) available at: https://www.prsindia.org/sites/default/files/bill_files/PRS\%20Legi slative\%20Brief\%20_4.pdf 
benefits period, the pregnant women can be laid off by the employer if the women employee shows gross misconduct and under $\S 12$ (a) $)^{83}$, a woman can be removed from employment if the employee pays out all her benefits. Similarly, there is nothing in the Act that acts as a deterrent for the employer to not take action against any woman who joins at the end of the benefits period. This effectively means that the employers are at complete freedom to remove woman employees on baseless grounds after benefits have been completely given to the woman employee. ${ }^{84}$

It could be said that the grounds of misconduct have been categorically defined under State Amendments to Maternity Benefit (Mines and Circus) Rules, 1963 and Maternity Benefit (Mines and Circus) Amendment Rules, 2017 but that does not impede the commercial actions of the employers to remove women employees from their deserved after the benefits have been allocated to them. Furthermore, the women employee has the right to prove her case by arguing in the mandatory hearing that must be provided to the woman employee before removing her from employment. Although the Act does not clearly mention anything in this regard, the High Court of Delhi in K. Chandrika v. Indian Red Cross Society and Anr ${ }^{85}$ held that even if the benefits are adequately allotted to the employees consequentially, it does not mean that the employer would be at freedom to terminate or remove the employee illegally through arbitrary means. Overall, the situation still remains confusing as it is not clear what will happen in the conditions mentioned above either under the Act or the Rules.

In a progressive manner, the employers are mandated to provide prior information of rights ${ }^{86}$ and benefits such as nursing breaks ${ }^{87}$,

83 National Tobacco Co. of India Ltd. and Ors. v. Fourth Industrial Tribunal and Ors, AIR 1960 Cal 249.

84 Aarefa Johari, Pregnancy remains a curse for working women in corporate India, QZ (April. 17th, 2015) available at: https:// qz.com/ 385866/ pregnancy-remains-a-curse-for-working-women-in-corporate-india/ 85131 (2006) D.L.T 585.

86 §11A (2), Maternity Benefits Amendment Act, 2017, Act No. 6 of 2017, Acts of Parliament, 2017 (India).

87 Rule 6 of the Maternity Benefit (Mines and Circus) Rules, 1963. 
exclude arduous labor for returning women employees 88 , medical bonus $^{89}$, tubectomy leave ${ }^{90}$, miscarriage leave ${ }^{91}$ and most importantly crèche facilities ${ }^{92}$ (Creche facilities are provided to the women employees within 500 meters of the establishment but it is not clear as to who would pay for the crèche facilities. Secondly with the number of nursing breaks amounting to two and crèche visits amounting to four, a woman is allowed a total number of six breaks. With such hotchpotch, the economic burden only increases on the employer who would then try to indulge in unwanted activities such as lay-off, retrenchment or may try to evade the cost of crèche and subsequent taxation on the same which maybe potently negative for the women employability interests) but what is lacking is, transparent demarcation for a situation involving conflict of interest of the employer and employee. Hence, appropriate amendments should be promulgated to lay down the law with respect to issues involving maternity benefits, during the pre-employment and post-employment period.

\section{Conclusion}

Throughout history, women have been subject to exploitation and unequal treatment and are struggling to maintain their status in this patriarchal society. Hence, there is a need to provide some reasonable leverage to the disadvantaged group. Social Security legislations are a step ahead in the validation of this argument. The reason for the falling numbers of women at work, is the little or no

$88 \S 4$ (3), Maternity Benefits Amendment Act, 2017, Act No. 6 of 2017, Acts of Parliament, 2017 (India).

$89 \S 8$, Maternity Benefits Amendment Act, 2017, Act No. 6 of 2017, Acts of Parliament, 2017 (India).

$90 \S 9$ (a),Maternity Benefits Amendment Act, 2017, Act No. 6 of 2017, Acts of Parliament, 2017 (India).

$91 \S 9$, Maternity Benefits Amendment Act, 2017, Act No. 6 of 2017, Acts of Parliament, 2017 (India).

92 Suresh Kumar, At work, crèche facilities for employees should be tax free; Here is Why, FINANCIAL EXPRES, (Sept. $8^{\text {th }}, 2017$ ) available at: https:/ / www.financialexpress.com/money/at-work-creche-facilitiesfor-employees-should-be-tax-free-here-is-why/846020/ 
realization of their rights and limited remedies available at their disposal. Even though the legislature has been fundamental in enacting statutes like The Maternity Benefits Act, 1961, adequate access and implementation remains a distant dream for millions of women across the country. Going by the judgment of B. Shah $v$. Presiding Officer, Labor Court, Coimbatore and the amended provisions in The Maternity Benefits Amendment Act, 2017, it can be observed that women need to be given extraneous benefits (Kerala High Court recognized 'Motherhood is the mother of all civilizations' though it did not rule anything in favor of women caring for children with disabilities or children in dire need of care), ${ }^{93}$ especially when they are vulnerable and the society should continuously thrive to reach a point when we can ensure a better space and living environment for all individuals of our diverse community.

The provisions of the Maternity Benefits Act, 1961 and the amended provisions must be made expressly applicable to women engaged in the unorganized sector and domestic helps, because of the worsening conditions of unorganized labor workforce. ${ }^{94}$ The scope of application of the Act must be made more expansive by removing the restriction of minimum 10 employees in an establishment under $\S 2$ of the Act, for the establishment to be bound by the terms of the Act. Such a step is necessary to ensure that women employed as domestic helps or on farms are not excluded from the application of the Act. ${ }^{95}$ The term 'week' and 'period' must be expressly defined in the Act, in the definitions clause under $\S 3$. Under the Amended Act, the period of eight weeks preceding the Date of Delivery as benefits, must be

${ }^{93}$ K. T. Mini v. Life Insurance Corporation of India, W.P.(C)No. 22007 of 2012, (2014) 15 SCC 300.

${ }^{94}$ The Challenge of Employment in India: An Informal Economy Perspective, NATIONAL COMMISSION FOR ENTERPRISES IN THE UNORGANIZED SECTOR, April, 2009.

95 Jovita Aranha, Preparing to Welcome a Baby? Here Are Maternity Benefits You Are Entitled To, THE BETTER INDIA, (Nov. 24 ${ }^{\text {th }}$,2017) available at: https:// www.thebetterindia.com/122251/maternity-benefits-law / 
increased to 12 weeks, as this would ensure that women get sufficient care and time to go ahead with the delivery.

The Sub $\S 5$ in the Amended Act which mentions work from home as a provision must be given clarity, as the mode of negotiation among the parties (The Employee and Employer) may otherwise be adversely affected. Scope for Alternative Dispute Resolution must be provided. There should be parity in benefits for 'commissioning mother' and 'adoptive mother'. Principally the reason for such parity is that both the commissioning mother and the adoptive mother go through the same hardship for nurturing and caring for the young child, by putting in an equal amount of time and intensive labor. Further, Paternity benefits should be expressly provided under the Act, as this would reflect the gender neutrality of the legislation and create a level playing field. The commercial interests of the employers must be equally balanced with the benefits imparted to women under the Act. Public disbursement schemes should be initialized on the lines of western economies, especially for the unorganized sector so that the employment opportunities of the women employees are not minimized. These schemes can be brought under the banner of direct benefits transfer schemes of the government, such as the 'Pradhan Mantri Jan Dhan Yojana'. Wage disparity based on gender must be reduced to facilitate increase in female workforce, as this would not only be socially just, but also economically sound. ${ }^{66}$ Benefits must be disbursed equally to women employees, irrespective of the number of children the women have under the new Act. This is particularly important considering the fact that there was no such distinction in the Maternity Benefits Act, 1961. ${ }^{97}$

96 Christine Lagarde, India should focus on women's inclusion ineconomy, FIRSTPOST, (Jan. 23rd, 2018) available at: http:// www.firstpost.com/ world/wef-2018-india-should-focus-on-womens-inclusion-in-economy -says- imf-chief-christine-lagarde-4315945.html

97 Radhika Iyengar, Maternity (Amendment) Bill: Looks good on paper, but there's more to it than what meets the eye, INDIAN EXPRESS, (March 10th, 2017) available at: https://indianexpress.com/article/opinion/webedits/maternity-amendment-bill-looks-good-on-paper-but-theresmore-to-it-than-what-meets-the-eye/ 